\title{
Estimating the Effects of Pronatal Policies on Residential Choice and Fertility
}

\author{
By
}

\section{Ryo Nakajima}

Ryuichi Tanaka

July 2012

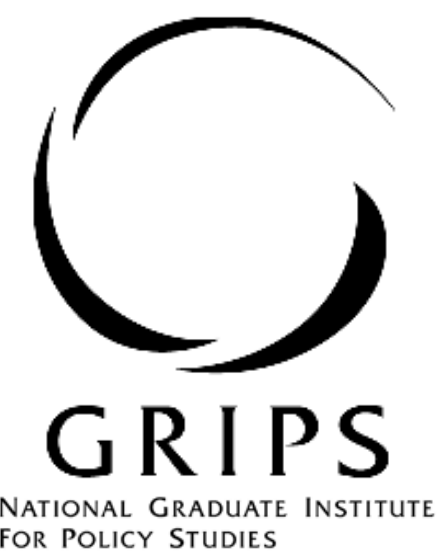

National Graduate Institute for Policy Studies

7-22-1 Roppongi, Minato-ku,

Tokyo, Japan 106-8677 


\title{
Estimating the Effects of Pronatal Policies on Residential Choice and Fertility*
}

\author{
Ryo Nakajima ${ }^{\dagger}$ \\ Yokohama National University
}

\author{
Ryuichi Tanaka \\ GRIPS
}

July 13, 2012

\begin{abstract}
In this paper, we estimate the impacts of local-government-sponsored pronatal policies on fertility by exploiting information on the geographical variation in policies across municipalities in Japan. We develop an empirical model that accommodates both the location and fertility choices of households to take into account their self-selected migration across municipalities. We estimate the structural parameters using cross-sectional microdata on Japanese households in metropolitan areas. The results suggest that self-selection may generate substantial upward bias in the estimated impacts of pronatal policies on fertility. We also find that, after controlling for self-selection bias, some types of noncash benefit pronatal policies significantly increase the probability of births occurring in metropolitan households, although the magnitudes differ significantly by revenue and birth parity.
\end{abstract}

JEL classification: J13, J61, H75.

Keywords: Fertility, family policies, residential location choice, selection bias.

\footnotetext{
*The authors thank Yukiko Abe, Akira Hibiki, Hidehiko Ichimura, Daiji Kawaguchi, Ayako Kondo, Chiaki Moriguchi, Masaki Nakabayashi, Kentaro Nakajima, Haruko Noguchi, Francesc Ortega, Katsuya Takii, Iichiro Uesugi, and seminar participants at the University of Tokyo, Hitotsubashi University, CUNY, and the National Institute for Environmental Studies, for detailed comments and suggestions. We are indebted to the Geospatial Information Authority of Japan (GSI) for providing geographic point information on municipal government offices. This project is financially supported by the Grant-in-Aid for Young Scientists (B) of the Japan Society for the Promotion of Science and by the GRIPS Research Center. All responsibility for errors remains with the authors.

†Department of Economics, Yokohama National University, 79-3 Tokiwadai, Hodogaya ward Yokohama 240-8501, JAPAN Tel: +81-45-339-3561, Fax: +81-45-339-3561. E-mail address: rn231@nyu.ac.jp

${ }^{\ddagger}$ National Graduate Institute for Policy Studies, 7-22-1 Roppongi, Minato-ku, Tokyo 106-8677, JAPAN Tel: +81-3-6439-6182, Fax: +81-3-6439-6182. E-mail address: rtanaka@grips.ac.jp
} 


\section{Introduction}

It is widely recognized that fertility rates in many OECD countries have been declining for decades. Figure 1 shows changes in total fertility rates over time for several OECD countries. From 1970 to the mid-1980s, every country experienced a decline in its fertility rate. In some countries, such as France and the United States, the fertility rate "rebounded" to the replacement rate (2.08). However, other countries such as Korea and Japan experienced a steady decline. In 2010, Korea and Japan had the lowest fertility rates among these countries.

\section{Insert Figure 1}

With fertility rates below replacement rates, OECD (2007) acknowledged that policies that make it easier - or less costly - to have children have become more important. In particular, given the experiences of rebounding to the replacement rate in the United States and Denmark from the mid-1980s and in France from the mid-1990s, they claim that these "successes" reflect the implementation of pronatal policies and arrangements that have made children more "affordable".

There is a large body of empirical research on the effects of pronatal policies on fertility in developed countries. As summarized by Gauthier (2007), most recent studies based on microdata focus on the impacts on fertility of either (i) cash benefit policies (e.g., family and child allowances, tax reduction, and tax credits) or (ii) noncash benefit policies (e.g., subsidized services for children and families, childcare provision, and maternity and parental leave). Generally, studies of cash benefit pronatal policies conclude that these policies have positive impacts on fertility, although the significance and magnitudes of the impacts vary greatly across household types and regions (e.g., to name a few, Milligan, 2005; Cohen, Dehejia and Romanov, 2007; Laroque and Salanié, 2008; Azmat and Gonzalez, 2010; Gonzalez, 2011; Brewer, Ratcliffe and Smith, 2011). Conclusions about the effects of noncash benefit pronatal policies are mixed (e.g., see Blau and Robins 1989, Del Boca 2002, and Andersson, Duvander and Hank 2004 for the effect of childcare; Ronsen 2004 and Lalive and Zweimuller 2009 for the effect of parental leave). Although these studies are well executed, they tend to be restricted to particular types of pronatal policies and tend to ignore others that are equally important. Because the magnitudes of some policy effects are not directly comparable with those of others across studies - policies are implemented at different times and places - it is not clear which pronatal policies are the most effective.

This paper contributes to the literature by quantifying rigorously the effects of pronatal policies on fertility. Our study differs from previous studies in that we estimate the impacts of various pronatal policies, including both cash benefit and noncash benefit policies, at the same time. We compare the "effectiveness" of different policies, and thus identify which policies have more impact on the fertility levels of which groups of households. In other words, unlike authors of previous empirical work, we evaluate the "price tags" of pronatal policies. 
Our identification strategy is based on the geographic variation of policies across regions. In particular, we exploit information on the variation in pronatal policies across municipalities in Japan. Indeed, Japan can be considered a suitable empirical testing ground, not only because of Japan's interest in the fertility issue, which derives from its low fertility rate, but also because of the large variation in policies across municipalities. In Japan, each local government is allowed to supplement nationally implemented pronatal policies using its own local budget. This policy implementation by local government generates substantial variation across municipalities, even in geographically small areas. This variation can be used to identify the effects on fertility of locally supported pronatal policies.

Another, and equally important, contribution of this paper is that we explicitly control for the self-selected migration decisions of households when evaluating the impacts of policies. As expected, if households consider the childbearing environment when deciding where to live, household residential locations are not exogenous to their fertility decisions. Thus, ignoring such self-selection will bias the estimated effects of pronatal policies on fertility. As does our study, previous studies exploit regional variations in pronatal policies (e.g., Del Boca, 2002; Andersson, Duvander and Hank, 2004; Milligan, 2005). However, none take into account the potentially endogenous migration decisions of households. For example, Milligan (2005) estimates the impacts of policy on fertility based on quasi-experimental data generated by the introduction of a cash benefit program in Quebec in the 1990s. He compares fertility levels in similar households in Quebec and those in other regions of Canada during the policy implementation period. Although selection into the program can be assumed to be exogenous within the state of Quebec, the selection across states may be endogenous because of residents' self-selected location decisions. Thus, if households selected themselves into (and out of) Quebec in the 1990s, the estimated impacts of the cash benefit program for the self-selected households might differ from those for randomly selected households.

In this paper, we develop an empirical model that accommodates households' migration and fertility decisions in order to control for self-selected migration. The model is analogous to a multimarket model of mobility and earnings Roy (1951). Unlike the original Roy model, we allow households to choose their residential municipalities, and to determine whether to have children. Following recent studies of residential location choice (e.g., Bayer, MacMillan and Rueben, 2005; Ferreira, 2010), we use a conditional logit model, which is analogous to the standard empirical model of product differentiation, to describe a household's choice of residential municipality. Then, we propose a "fertility regression" that relates a household's childbearing decision to various fertility-related factors, including household characteristics, as well as municipality attributes and pronatal policies. We address the issue of self-selection bias by using a variant methodology proposed by Dahl (2002). Following Dahl, we estimate the fertility regression with a correction term for self-selected migration, which is a function of the propensity for a household to choose its residential municipality. 
Our main data source is Japan's 2004 Family Income and Expenditure Survey (JFIES), conducted by the Statistics Bureau of the Ministry of Internal Affairs and Communications (MIAC). The JFIES is a nationally representative household survey of Japan that provides information on a variety of household characteristics such as family structure, household income, and place of current residence. We match data for households living in metropolitan areas with data on the municipalities in which households are resident. For information on municipality-sponsored pronatal policies, we use a survey report conducted by the Cabinet Office of Japan in 2004. Of the policies discussed in the survey, we focus on those that are directly related to fertility decisions: (1) Child Allowance and Child Birth Allowance; (2) Medical Subsidy for Infants and Children; (3) Health Checkup Services for Pregnant Women, Infants, and Children; (4) Daycare Services Expenses; and (5) Community-based Childbearing Support. We estimate the impact of these local-government-sponsored pronatal fertility policies for metropolitan households in Japan.

The main results of this paper are as follows. First, there is evidence that households select themselves into and out of municipalities based on pronatal policies. Our estimation results suggest that such self-selection may substantially bias upward the estimated fertility impacts of pronatal policies. Second, after controlling for self-selection, it is found that Community-based Support policies significantly increase the probability of additional children in metropolitan households with at least one child, in which the husband's annual income is below three million yen. Moreover, for metropolitan households in which the husband's annual income exceeds four million yen, there is evidence that Health Checkup Services policies have a significantly positive impact on the probability of having a first child. Although the impacts of these noncash benefit policies are significantly positive, the magnitudes are small. Our estimation results suggest that a 10 percent increase in Community-based Support policy expenditure results in a 0.1 to 0.3 percent increase in the probability of having a first child. A 10 percent increase in Health Checkup Services policy expenditure raises the probability of having an additional (to the first) child by between 0.5 and 0.9 percent.

The remainder of the paper is organized as follows. In Section 2, we explain childrearing support policies in Japan. In Section 3, we develop the econometric model and describe the estimation procedure. In Section 4, we explain the data used for estimation. In Section 5, we report the estimation results. Section 6 concludes the paper.

\section{Recent Childrearing Support Policies in Japan}

In response to a steady decline in Japan's fertility rate, the Japanese government has taken various policy measures to promote fertility. One of the main policies is a cash benefit - a child allowance granted universally according to the number of dependent children in a family. This started in 1971 and was subsequently expanded in incremental steps, with measures designed to widen eligibility being 
introduced in the 1990s. As of September 2004- the month in which our data were collected - the first and second children received 5,000 yen per month, and the third and subsequent children received 10,000 yen per month, until they reached nine years of age. Furthermore, the government implemented various noncash benefit policies in the mid-1990s to establish an environment in which women could give birth without anxiety. Under two five-year childrearing support policy plans, the so-called "Angel Plan" (for 1995 to 1999), and the "New Angel Plan" (for 2000 to 2004), the government implemented several measures, including the enhancement of childcare leave benefits, improvements to the quality and quantity of day care services, and the provision of more facilities for the care of infants and children.

Local government has also taken responsibility for implementing childrearing support measures, in coordination with the central government ministries and agencies concerned. Indeed, municipalities have introduced central-governmentsponsored pronatal policies as central-local government joint projects, with subsidies (disbursements) being allocated from the central government. In the process, each municipality has some discretion in augmenting projects by using its own budget to meet residents' needs and demands. The leeway accorded local governments has created regional disparities in childrearing support services across municipalities. This disparity is used to identify the impacts of policy on fertility.

The Local Government Childrearing Support Policies Survey, conducted by the Cabinet Office in 2004, summarizes local-government-sponsored pronatal policies. They can be categorized into five policy areas.

Child Allowance and Childbirth Allowance: Some municipalities offer a child allowance and/or childbirth allowance, in addition to the nationally implemented child allowance. The child allowance is paid for a given period of time until the child reaches a certain age, whereas the childbirth allowance is paid only at birth. According to the Cabinet Office Survey, hardly any municipalities (3.5 percent) adopted the local-government-sponsored child allowance, whereas about a quarter of municipalities (25.5 percent) adopted the childbirth allowance. The Cabinet Office Survey reports substantial cross-municipality variation in the payment amounts and eligibility conditions of the child and childbirth allowances.

Medical Subsidy for Infants and Children: In Japan, basic medical treatment expenses are covered by public insurance. Under the scheme, patients generally pay 30 percent of all medical costs. The Cabinet Office Survey reports that almost all (97.5 percent) municipalities offered additional financial support to low-income households for medical expenses related to infants and children, and for illness not covered by public insurance. Usually, to receive the medical subsidy, households must meet income limit requirements and children must be below a certain age. The income and age limit requirements vary greatly across municipalities, as reported in the Cabinet Office Survey. 
Health Checkup Services for Pregnant Women, Infants, and Children: Under the Japanese insurance system, health checkups for pregnant women, infants, and children are outside the scope of publicly insured medical treatments. Hence, according to the Cabinet Office Survey, most municipalities (57.9 percent) subsidized health checkup expenses in an effort to raise fertility. The subsidy allows many households to undergo medical examinations for pregnant women, infants, and children a dozen times for free. Although the costs of free checkups are borne by the municipalities, the frequency and availability of these free services are set independently by each municipality.

Daycare Services Expenses: In Japan, municipal governments are responsible for admitting to day care centers children whose parents cannot care for them when they are at work. Because municipalities operate public day care centers directly and often subsidize private day care centers in their administrative regions, expenditure on day care services is considered a noncash benefit to households with children. The Cabinet Office Survey reveals that, on average, the number of day care centers, including both public and private ones, is 6.8 per municipality, and the per-facility number of children is 89.8 for public day care centers and 102.0 for private day care centers. Generally, municipal day care centers are cheaper than private ones, but the former have relatively limited capacity. Wide variations in childcare fees across municipalities reflect corresponding differences in expenditure levels.

Community-based Childrearing Support: Municipalities have promoted community-based activities in order to enhance comprehensive childrearing support measures. The Cabinet Office Survey reports that 60.4 percent of municipalities used their local budgets to construct and/or operate special purpose facilities, termed Local Community Centers for Childrearing Support (Chīki Kosodate Shien Sentā, in Japanese), which offer space and opportunities for parents with infants and children to communicate with each other, and to provide counseling courses and lectures by professionals and experts about childrearing and home education. As of 2004, there were, on average, two such local community centers per municipality (primarily in urban areas), with substantial variation across municipalities.

\section{Baseline Model}

Suppose that there are $I$ households and $J$ municipalities. We assume that the fertility function of household $i$ living in municipality $j$ is given by the following equation:

$$
y_{i j}=x_{i} \beta_{x}+s_{j} \beta_{s}+t_{j} \beta_{t}^{i}+\omega_{i j},
$$

where $y_{i j}$ is the fertility outcome; i.e., whether household $i$ living in municipality $j$ has children or not. We use $x_{i}, s_{j}$, and $t_{j}$ to denote household and 
municipality characteristics; $x_{i}$ is a vector of attributes of household $i$, and $s_{j}$ and $t_{j}$ are vectors of amenity attributes and pronatal policies of municipality $j$, respectively. Given the structural parameters of the fertility equation, $\beta_{x}$, $\beta_{s}$, and $\beta_{t}^{i}$, we focus on the effects of pronatal policies on the fertility outcome, namely $\beta_{t}^{i}$, which is assumed to be heterogeneous across households:

$$
\beta_{t}^{i}=\beta_{0 t}+\sum_{k=1}^{K} \beta_{k t} x_{k i}
$$

where $k$ indexes household characteristics. The parameter $\beta_{k t}$ measures the impact of pronatal policy $t_{j}$ on household $i$ with characteristic $x_{k i}$. ${ }^{1}$ We let $\omega_{i j}$ be an i.i.d. idiosyncratic random shock to the fertility outcome.

We consider a horizontal sorting model in which each household's residential location is chosen to maximize utility. Following recent studies of households' residential location decisions (e.g., Bayer, MacMillan and Rueben, 2005; Ferreira, 2010), we use a specification analogous to the standard differentiated product demand model proposed by Berry, Levinsohn and Pakes (1995). We assume that each household chooses its residential municipality by taking childrearing into consideration. In this setup, we consider each municipality as a bundle of characteristics that provides utility to the households there. Thus, residential locations are chosen from among municipalities. Let $V_{i j}$ be the utility derived by household $i$ from living in municipality $j$. Then we assume:

$$
V_{i j}=\theta_{y} y_{i j}+s_{j} \theta_{s}+t_{j} \theta_{t}^{i}-r_{j} \theta_{r}+\xi_{j}+\varepsilon_{i j},
$$

where $r_{j}$ is the residential land price, $\xi_{j}$ denotes the unobserved local amenity attributes of municipality $j$ that are common to all households in that municipality, and $\varepsilon_{i j}$ is an i.i.d. idiosyncratic taste shock. In this specification, the residential land price, $r_{j}$, serves as an exclusion restriction. We assume that it affects a household's decision about which municipality to live in, but does not directly affect its fertility decision (i.e., whether to have children).

Because the municipality-specific attributes, $s_{j}$ and $t_{j}$, affect the location utility both directly and indirectly through childbearing $y_{i j}$, we have the following reduced-form indirect utility function:

$$
\begin{aligned}
V_{i j} & =s_{j}\left(\theta_{s}+\theta_{y} \beta_{s}\right)+t_{j}\left(\theta_{t}^{i}+\theta_{y} \beta_{t}^{i}\right)-r_{j} \theta_{r}+\xi_{j}+\left(\theta_{y} \omega_{i j}+\varepsilon_{i j}\right) \\
& =s_{j} \gamma_{s}+t_{j} \gamma_{t}^{i}-r_{j} \gamma_{r}+\xi_{j}+v_{i j} .
\end{aligned}
$$

The above expression incorporates the following reparameterization: $\gamma_{s}=\theta_{s}+$ $\theta_{y} \beta_{s}, \gamma_{t}^{i}=\theta_{t}^{i}+\theta_{y} \beta_{t}^{i}, \gamma_{r}=\theta_{r}$, and $v_{i j}=\theta_{y} \omega_{i j}+\varepsilon_{i j}$. Note that the householdspecific characteristics, $x_{i}$, which drop out of the equation because they do not vary across municipalities, do not affect municipality choice.

\footnotetext{
${ }^{1}$ We do not include unobserved heterogeneity in this empirical model. Because our microdata provide a rich set of household characteristics, we consider the observed heterogeneity sufficient to capture household decisions on fertility and residential location flexibly. See, e.g., Ferreira (2010) for a location choice model without unobserved heterogeneity.
} 
Because each household chooses the municipality that maximizes its indirect utility, household $i$ chooses to live in municipality $j$ if and only if $V_{i j}=$ $\max \left(V_{i 1}, \cdots, V_{i J}\right)$. We assume that the random shock, $v_{i j}$, in Eq.(3), follows an i.i.d.-type one extreme value distribution. Let $p_{i j}$ be the propensity of household $i$ to live in municipality $j$; i.e., $p_{i j}=\operatorname{Prob}\left(d_{i j}=1 \mid x_{i}, s_{j}, t_{j}, r_{j}, \xi_{j}\right)$. This generates the following conditional logit probability:

$$
p_{i j}=\frac{\exp \left(s_{j} \gamma_{s}+t_{j} \gamma_{t}^{i}-r_{j} \gamma_{r}+\xi_{j}\right)}{\sum_{k} \exp \left(s_{k} \gamma_{s}+t_{k} \gamma_{t}^{i}-r_{k} \gamma_{r}+\xi_{k}\right)} .
$$

The household's fertility outcome is affected by its self-selected municipality choice. Indeed, a household's fertility outcome is not observed for all municipalities but only for the municipality in which the household chooses to live. Let $d_{i j}$ be an index that is unity if household $i$ lives in municipality $j$, and zero otherwise. Then, we have the following fertility equation for the observed $y_{i j}$ :

$$
y_{i j}=x_{i} \beta_{x}+s_{j} \beta_{s}+t_{j} \beta_{t}^{i}+\mathrm{E}\left(\omega_{i j} \mid d_{i j}=1, x_{i}, s_{j}, t_{j}, r_{j}, \xi_{j}\right)+\eta_{i j}
$$

where $\mathrm{E}\left(\omega_{i j} \mid \bullet\right)$ represents the selection bias for household $i$, and $\eta_{i j}$ is an i.i.d. error term with zero mean conditional on the observable household-specific and municipality-specific characteristics. Because of horizontal sorting behavior by households, the selection bias term, $\mathrm{E}\left(\omega_{i j} \mid \bullet\right)$, is not equal to zero, in general. As noted by Dahl (2002), this term is a function of household probabilities of residential choice across municipalities. Hence, we can rewrite Eq.(5) as follows:

$$
y_{i j}=x_{i} \beta_{x}+s_{j} \beta_{s}+t_{j} \beta_{t}^{i}+\mathrm{E}\left(\omega_{i j} \mid p_{i 1}, \cdots, p_{i J}\right)+\eta_{i j} .
$$

For estimation, we approximate the conditional expectation term, $\mathrm{E}\left(\omega_{i j} \mid p_{i 1}, \cdots, p_{i J}\right)$, by using a flexible polynomial function of estimated location choice propensities, $\hat{p}_{i 1}, \cdots, \hat{p}_{i J}$.

\section{Data}

Our main data source is the 2004 JFIES, conducted by the Statistics Bureau of the MIAC. The JFIES provides information on a variety of household characteristics for about 9,000 randomly selected households in Japan, except institutional households and one-person student households.

To sharpen the focus of the paper, we limit our sample to metropolitan households with a husband and wife located in one of Japan's four major metropolitan areas of Tokyo, Osaka, Nagoya, and Fukuoka. ${ }^{2}$ In addition, given that we are analyzing households' fertility decisions, we restrict our sample to include only households with a wife of childbearing age, i.e., between 16 and

\footnotetext{
${ }^{2}$ Each major metropolitan area, defined by the MIAC, comprises a core government-decreed city (e.g., the Tokyo Metropolitan Government for the Tokyo Metropolitan Area, and Osaka City for the Osaka Metropolitan Area) and the suburban cities surrounding it. The combined population of the four major metropolitan areas represents 53 percent of Japan's total population.
} 
50. Further, we include only households of more than three years' residence. In doing so, we assume that only the childbearing decisions of such "long-term" residential households are amenable to influence by the pronatal policies of the municipalities in which they currently reside.

We define the fertility outcome according to whether the household gave birth to at least one child between September 2001 and September 2004. Because of the cross-sectional nature of the JFIES, we can use its survey information on household configuration to determine the fertility outcome for each household. Information on other household characteristics relates to September 2004, when the interviews were conducted.

The data on household characteristics obtained from the JFIES are complemented by information on the characteristics of municipalities. ${ }^{3}$ Information on these municipality characteristics - including the price of residential land, the crime rate, the unemployment rate, the rented housing proportion, the fiscal soundness index, the number of medical doctors per person, the number of college graduates per person, and the number of supermarket stores per person - is obtained from various sources. (Detailed descriptions and data sources are in the Appendix.)

Information on pronatal policies is taken from the Local Government Childrearing Support Policies Survey, conducted by the Cabinet Office of Japan in 2004. In this survey, municipality representatives were asked a battery of questions about their pronatal policies. For the selected municipalities in the four major metropolitan areas, response rates were as high as 73 percent. $^{4}$ We focus on five major pronatal policies: (1) Child Allowance and Child Birth Allowance; (2) Medical Subsidy for Infants and Children; (3) Health Checkup Services for Pregnant Women, Infants, and Children; (4) Daycare Services Expenses; and (5) Community-based Childbearing Support. These policy variables are measured by expenditure amounts (in 10,000 yen) per child aged up to 15 . We consider only the expenditures financed by municipalities' own funds; those transferred from the central government are excluded.

Table 1 reports the descriptive statistics of the selected variables for the selected sample. The top panel (Panel A) displays statistics on householdspecific characteristics, and the bottom panels (Panels B and C) report the information on municipalities' pronatal policies used for estimation. Sampled units differ between panels: Panel A reports information on 5,697 households, and Panels B and C report information on 277 municipalities; these figures imply an average of 20 sampled households per municipality. Municipalities differ greatly in terms of spending on pronatal policies. In descending order, the major items of expenditure are on Daycare, Medical Subsidy, and Health Checkups. The largest correlation coefficient (0.43) is the one between Child Allowance and Medical Subsidy. Generally, municipalities' pronatal policies are not highly correlated with each other.

\footnotetext{
${ }^{3}$ In Japan, the four types of municipality (of government-decreed cities) are the city, town, village, and ward.

${ }^{4}$ The survey response rate for all the municipalities, including those outside the four major metropolitan areas, was about 60 percent.
} 


\section{Insert Table 1}

Spending on pronatal policies varies greatly across municipalities. Figure 2 plots quartile variations of per-child pronatal policy expenditures for municipalities in the Tokyo Metropolitan Area. ${ }^{5}$ The figure reveals substantial variations in pronatal policy expenditures - even among proximate municipalitiesbut suggests no systematic geographical patterns across municipalities.

\section{Insert Figure 2}

\section{Empirical Results}

We estimate the model in two stages. In the first stage, we estimate the model of household location choice, and in the second stage, we estimate the model of household fertility decisions.

\subsection{Municipality choice}

We estimate the structural model of the household's location choice as outlined in Section 3. Given the conditional logit model specification, the probability of household $i$ choosing location $j$ is given by Eq.(4). We construct the likelihood function based on the choice probability and maximize the likelihood with respect to the structural parameters.

The location choice probability model includes the residential land price, $r_{j}$, and a vector of local amenities, $s_{j}$, and pronatal policies, $t_{j}$, as independent variables. We assume that these characteristics are exogenous from the individual household's perspective, after taking into account preferences over unobserved location factors, $\xi_{j}$. Given that $\gamma_{t}^{i}$ represents the household-specific pronatal policy effect on residential location choices, we interact the variable $t_{j}$ with two household characteristics, $x_{i}$-husband annual income and a dummy variable for whether the household already has children - as indicated by Eq.(2). This specification allows household tastes for different municipalities to vary with household characteristics, and produces flexible substitution patterns across municipalities for each household.

There are potential endogeneity issues in the location choice model. Given that land prices tend to be higher for municipalities with valuable unobserved local amenities, the residential land price, $r_{j}$, may be correlated with the unobserved municipality-specific attributes, $\xi_{j}$. To deal with this endogeneity issue, following recent empirical studies of consumer demand (e.g., Petrin and Train, 2010; Ferreira, 2010), we use a control function approach. The idea is to use that part of the residential land price, $r_{j}$, that is independent of indirect location utility to proxy the unobserved municipality-specific attributes, $\xi_{j}$. Let $z_{j}$ denote instrumental variables (IVs) that directly affect land prices, $r_{j}$, but are

\footnotetext{
${ }^{5}$ The quartile-variation maps of the other metropolitan areas are available from the authors on request.
} 
uncorrelated with the location utilities for households living in municipality $j$. Hence, we have the following "hedonic" equation:

$$
r_{j}=s_{j} \phi_{s}+t_{j} \phi_{t}+z_{j} \phi_{z}+\nu_{j}
$$

Note that the unobserved $\nu_{j}$ makes $\xi_{j}$ and $r_{j}$ correlated with each other. In the control function approach, a flexible function for $\nu_{j}$ is used to approximate the unobserved municipality-specific attributes, $\xi_{j}$, included in the location choice probability model.

For estimation, we run the hedonic regression, Eq.(7), and obtain the residuals, $\hat{\nu}_{j}$, for each municipality $j$. With $\mu(\bullet)$ being a flexible function of the residual, we estimate the following conditional logit model:

$$
p_{i j}=\frac{\exp \left(s_{j} \gamma_{s}+t_{j} \gamma_{t}^{i}-r_{j} \gamma_{r}+\mu\left(\hat{\nu}_{j}\right)\right)}{\sum_{k} \exp \left(s_{k} \gamma_{s}+t_{k} \gamma_{t}^{i}-r_{k} \gamma_{r}+\mu\left(\hat{\nu}_{k}\right)\right)} .
$$

The household's estimated location choice propensities, $\left\{\hat{p}_{i 1}, \cdots, \hat{p}_{i J}\right\}$, are, in turn, used to construct the flexible polynomial function of $\mathrm{E}\left(\omega_{i j} \mid p_{i 1}, \cdots, p_{i J}\right)$ in the fertility regression, Eq.(6).

We instrument the endogenous residential land price of a specific municipality by using the average pronatal policies of neighboring municipalities. Let $n(j)$ be the set of municipalities neighboring municipality $j$. We use the average pronatal policies of these neighboring municipalities as instruments for the residential land price: $z_{j}=\frac{1}{|n(j)|} \sum_{j \in n(j)} t_{j}$. Using these IVs is reasonable because of the way the housing market works: housing demand in municipality $j$ is affected by housing demand in neighboring municipalities, $n(j)$. Thus, the residential price, $r_{j}$, is affected by policies pursued in neighboring municipalities. On the other hand, because a household in municipality $j$ benefits only from that municipality's policy, the household's location utility is unaffected by the pronatal policies of neighboring municipalities. This implies that the average policies of neighboring municipalities, $z_{j}$, are correlated with the residential land price, $r_{j}$, but are uncorrelated with the preference shock, $\eta_{i j}$, of household $i$ living in municipality $j$.

Another issue in estimating the location choice model, given by Eq.(8), involves the specification of the household's choice set. We assume that each household compares the utility levels derived from living in different municipalities, and chooses to live in the one that yields the highest residential utility. For estimation, we assume that the set of possible alternatives comprises proximate municipalities. To be specific, we consider municipalities within a $30 \mathrm{~km}$ radius of the current resident municipality. ${ }^{6}$

Table 2 reports the estimation results from the household location choice regression. Column 1 reports the estimated coefficients from the model that does not include the hedonic residual. In this specification, the land price is assumed to be exogenous. Column 2 reports the estimated coefficients of the model that controls for potential endogeneity of the land price by including a

\footnotetext{
${ }^{6}$ On average, 30.7 municipalities are included in the alternative choice set.
} 
polynomial function of the hedonic residuals. In both specifications, we approximate the function $\mu(\bullet)$ by using a third- order polynomial of the hedonic residuals. As shown, the coefficients of the hedonic residuals used to control for the endogeneity of land prices are statistically significant. To test for the endogeneity of the land price, we perform a Hausman-type test based on the difference between the estimates in columns 1 and 2 . We find that the null hypothesis of an exogenous land price is rejected at the one percent significance level. ${ }^{7}$ Thus, in what follows, we assume that the land price is endogenous, and predict the propensity to control for self-selected migration using the estimation results given in column 2 .

\section{Insert Table 2}

Overall, the estimated parameters have reasonable signs. Columns 1 and 2 show the robust finding that households tend to select themselves into municipalities with lower crime rates, lower unemployment, and higher rented housing proportions. Focusing on the municipality-sponsored pronatal policies that may drive households' location decisions, we find that households are more likely to move into municipalities in which Community-based Support policy is more prevalent. The estimated parameter on the interaction term between pronatal policy and household characteristics indicates that location preferences depend on whether households already have children: households with children are significantly more likely to locate in municipalities in which Health Checkup Services policy is more prevalent than are those without children. This suggests that household migration decisions across municipalities lead to different estimated effects on fertility than those that would be observed if household residential municipalities were randomly assigned. In what follows, we analyze the effects of pronatal policies on households' fertility decisions more closely after controlling for their self-selected migration decisions.

\section{$5.2 \quad$ Fertility choice}

Having estimated the household's location choice model in the first stage, we estimate the fertility decision model in the second stage. As discussed earlier, the model of the household's fertility decision is given by Eq.(6). The dependent variable, $y_{i j}$, is a dummy variable indicating whether at least one child was born between 2001 and 2004 in household $i$ in municipality $j$. The regression model includes household characteristics, $x_{i}$, as regressors; i.e., the wife's age, the husband's age, the husband's annual income, a dummy for preexisting children, and a dummy for whether the wife works. Also included are the municipalityspecific attributes, $s_{j}$ and $t_{j}$, which are also included in the location choice

\footnotetext{
${ }^{7}$ The Hausman test of exogeneity is based on comparing an efficient consistent estimator with an inefficient consistent estimator. In our scenario, under the null hypothesis that the land price is exogenous, the estimators used in columns 1 and 2 are both consistent, but the former is more efficient than the latter. The Hausman test statistic is 8.08. Given that the asymptotic distribution of the test statistic is $\chi^{2}$ with one degree of freedom under the null hypothesis, the p-value is 0.004 .
} 
model. In this specification, the parameter of interest is the effect of pronatal policy on fertility, $\beta_{t}^{i}$. This parameter is allowed to vary with two household characteristics: the husband's annual income and the dummy for preexisting children.

In the fertility regression, we approximate the self-selection correction term by using a function of household predicted propensities for residential locations. Following Dahl (2002), we make the simplifying assumption that the correction term can be suitably approximated by the household's first-best location choice propensity; i.e., the propensity that the household chooses the municipality in which it currently resides. ${ }^{8}$ Thus, we consider the following single-index correction term:

$$
\mathrm{E}\left(\omega_{i j} \mid p_{i 1}, \cdots, p_{i J}\right)=\lambda\left(\hat{p}_{i j}\right),
$$

where $\hat{p}_{i j}$ is the predicted propensity that household $i$ chooses municipality $j$ (in which it currently resides), which is obtained from the first-stage estimation, and $\lambda(\bullet)$ is a flexible function of the location propensity.

There is one remaining estimation issue. The dummy variable indicating whether the wife works is potentially endogenous in the fertility regression. Not only is the wife's decision to have children affected by whether she works, her decision to work is also affected by whether she has children. This would bias the estimates by causing the wife's labor force participation dummy to be correlated with the error term in the fertility regression.

To deal with this endogeneity issue, we use IV estimation. Our choice of instruments exploits the "discontinuity" in household taxation that arises in Japan because spousal deductions are subject to a threshold. In Japan, if a spouse (usually the wife) has gross annual earnings of less than 1.03 million yen (in 2004), the primary earner (usually the husband) is entitled to the spousal tax deduction. As is widely argued in the literature (see, e.g., Akabayashi, 2006), the tax deduction provides a working wife with a strong incentive to keep her income below the spousal deduction eligibility threshold. At the same time, because the spousal deduction reduces the primary earner's taxable income, households in which the husband's income is relatively high can claim a larger deduction when the wife' gross income is below the threshold.

Figure 3 illustrates the difference in annual tax deductions between a household in which the wife earns less than the spousal deduction eligibility threshold and one in which the wife earns more than the threshold, as a function of the husband's gross annual income, denoted by $s$. The figure shows that the former household can claim a bigger tax deduction than the latter household, and the difference in the deductible tax amount increases drastically (almost "discontinuously") at points where the husband's marginal tax rates change; i.e., around annual incomes of $s=4.83$ and $s=11.31$ million yen. Because the reward for not working is greater for a wife with a higher-income husband facing a

\footnotetext{
${ }^{8}$ This assumption, known as the index sufficiency assumption, implies that the choice probability contains sufficient information to describe the joint probability of the error term in the selection and outcome equations.
} 
higher marginal tax rate, a wife whose husband earns just above the marginal tax threshold has less of an incentive to work than does a wife whose husband earns just below the marginal tax threshold, all else equal.

\section{Insert Figure 3}

This suggests using dummy variables indicating whether the husband's annual income is above the marginal tax threshold as IVs for the wife's labor force participation. Specifically, we consider the following cut-off dummy variable IVs:

$$
1\left(s_{i}>4.83\right) \text { and } 1\left(s_{i}>11.31\right)
$$

where $s_{i}$ is the husband's annual income for household $i$. These cut-off dummy variables are expected to be negatively correlated with the likelihood of the wife working. Because the alignment of the husband's annual income relative to the cut-off values is unrelated to childbearing decisions, these cut-off dummies are uncorrelated with the unobserved factors that affect household fertility decisions.

We follow Das, Newey and Vella (2003), who proposed a control function regression approach that takes into account both self-selection and endogenous regressors. Like the usual IV estimation method, it involves a two-stage regression procedure. In the first stage, given the cut-off dummy IVs, $1\left(s_{i}>4.83\right)$ and $1\left(s_{i}>11.31\right)$, we run a "wife's labor force participation regression", with the dependent variable being the wife's working dummy. Then, in the second stage, we run the control-function-augmented fertility regression. In this stage, we include the following "double-index" control function:

$$
\mathrm{E}\left(\omega_{i j} \mid p_{i 1}, \cdots, p_{i J}\right)=\lambda\left(\hat{p}_{i j}, \hat{\zeta}_{i j}\right)
$$

The function $\lambda$ is a flexible function of the predicted propensity of a household to choose a given municipality, $\hat{p}_{i j}$, and the residual from the wife's labor force participation regression, $\hat{\zeta}_{i j}$. Although there are nonparametric techniques for estimating the unknown control function $\lambda$, we use a polynomial approximation. We approximate the function $\lambda\left(\hat{p}_{i j}, \hat{\zeta}_{i j}\right)$ by using a higher-order polynomial in the propensity, $\hat{p}_{i j}$, the residual, $\hat{\zeta}_{i j}$, and a cross-product term of the polynomials of $\hat{p}_{i j}$ and $\hat{\zeta}_{i j}$. To determine the orders of the polynomials, we follow Das, Newey and Vella $(2003)$ by using the cross-validation $(\mathrm{CV})$ procedure. ${ }^{9}$

Table 3 reports the estimation results for the wife's labor force participation regression, which is used to obtain the residual, $\hat{\zeta}_{i j}$, for the control function. Given that the regression is a reduced-form equation, we control for all the individual and municipality characteristics that are assumed to be exogenous in the municipality choice and fertility choice regressions. We also include a quadratic term in $s_{i}$ to accommodate potential nonlinearity between a wife's working incentive and her husband's annual income. ${ }^{10}$ The estimated effects

\footnotetext{
${ }^{9}$ The CV results are available from the authors on request.

${ }^{10}$ We tried higher-order polynomial terms in $s_{i}$, but found that all the terms higher than the second- order ones were statistically insignificant.
} 
of the household and municipality characteristics seem reasonable. One of the cut-off dummy IVs, $1\left(s_{i}>11.31\right)$, has the expected sign and is statistically significant.

\section{Insert Table 3}

Given the estimated propensity score and the residual from the wife's labor force participation regression, we include the control function in the fertility regression. The estimation results are reported in Table $4 .{ }^{11}$ The first two columns report the benchmark results without self-selection controls. Column 1 reports the OLS estimates and column 2 shows the IV estimates, which take account of the endogeneity of the wife's labor force participation. ${ }^{12}$ The last two columns show the estimation results with self-selection controls. In these specifications, because the "double-indexed" control function, $\lambda\left(\hat{p}_{i j}, \hat{\zeta}_{i j}\right)$, is included, both the self-selected migration of households and the endogeneity of working wives are dealt with. ${ }^{13}$ Column 3 reports the estimation results for the specification that minimized the $\mathrm{CV}$ criteria: the specification comprises cubic terms for both propensity, $\hat{p}_{i j}$, and the residual, $\hat{\zeta}_{i j}$, and an interaction term of a linear propensity and residual. Column 4 reports the estimation results for the "undersmooth" specification of the minimized CV model. Because nonparametric theory requires one to "undersmooth" the model by including sufficiently higher-order polynomial terms in the control function, we use the model reported in column 4 as our preferred specification for the self-selectioncorrected fertility regression model.

\section{Insert Table 4}

It is clear from columns 3 and 4 that some of the coefficients in the control function are statistically significant from zero. The null hypothesis that all the coefficients of the control function are jointly insignificant is rejected at below the one percent significance level by a Wald test. ${ }^{14}$ These results confirm that households' self-selection plays an important role in their fertility decisions.

In relation to the impacts of municipality-sponsored pronatal policies on fertility, not all estimated coefficients are statistically significant, even after

\footnotetext{
${ }^{11}$ Following previous studies, we trim 2.5 percent of the data based on the values of the propensity, $\hat{p}_{i j}$, and the residual, $\hat{\zeta}_{i j}$, from each tail.

${ }^{12}$ The IV estimator is often termed a control function estimator because the inclusion of the residual controls for the endogeneity of the regressor. It is shown by (see, e.g., Wooldridge, 2010) that the estimate is numerically identical to an ordinary two-stage least-squares estimate.

${ }^{13}$ Given that we include the predicted component rather than the actual component, the naive standard errors must be corrected to take account of sampling errors. We therefore use a bootstrap procedure with 3,000 replications to correct for the extra sampling variability arising from imputing the predicted values of $\hat{p}_{i j}$ and $\hat{\zeta}_{i j}$. The statistical significance of the estimates is based on bootstrap $t$ confidence intervals.

${ }^{14}$ The Wald test statistics are 98.65 and 109.67 for the specifications reported in columns 3 and 4 , respectively, which are asymptotically distributed as $\chi^{2}$ with 9 and 11 degrees of freedom, respectively.
} 
controlling for self-selected migration. Moreover, policy impacts are quite heterogeneous across subgroups of households. The estimated coefficients of the interaction terms between pronatal policy and household characteristics show that Community-based Support and Health Checkup Services affect the probability of childbirth for different types of households differently. In particular, Community-based Support policy has a greater positive impact on fertility, regardless of birth parity, in households with low-income husbands than it does in households with high-income husbands. By contrast, Health Checkup Services policy is relatively more effective at increasing the probability of first births for households without preexisting children than it is at raising the probability of households with a preexisting child having more children.

To get a sense of the impacts of fertility policies, we compute the marginal effects for various subgroups of households that are categorized based on the husband's annual income and whether they already had any children. Table 5 shows the results. Figures represent percentage changes in the estimated probability of childbirth induced by 10 percent increases in pronatal policy expenditure. The specification used is the undersmoothed self-selection control model presented in column 4 of Table 4 . As shown, the policy impacts exhibit complex patterns, with magnitudes depending on husband income and birth parity. The figures reveal that Community-based Support policy has significantly positive effects on the probabilities of having second or later children for metropolitan households with husbands whose annual income is below three million yen. We find that Health Checkup Services policy has a significantly positive impact on the probability of having a first child for metropolitan households in which husbands' annual earnings exceed four million yen. Interestingly, no other pronatal policy has a significant impact on fertility. We also find that, although Communitybased Support and Health Checkup Services policies have significantly positive impacts on fertility, the magnitudes are small. Our estimates suggest that a 10 percent increase in Community-based Support policy results in an increase in the probability of having a first child of between 0.1 and 0.3 percent. Similarly, a 10 percent increase in Health Checkup Services policy raises the probability of having additional children by between 0.5 and 0.9 percent.

\section{Insert Table 5}

It is important to quantify the size of the bias in the estimated effects of policy on fertility when households' self-selected migrations are not considered. For clarity, Figure 4 provides a graphical representation of the marginal effects of policies on fertility and compares them across the OLS, IV, and the undersmoothed self-selection control models, which correspond to the estimation results reported in columns 1, 2, and 4 of Table 4, respectively. The top figure shows the marginal effects of Community-based Support policy on the probability of a household having a first child, whereas the bottom figure shows the marginal effects of Health Checkup Services policy on the probability of households having additional (to the first) children. The marginal effects are evaluated for household groups with different levels of husband income. 
The figure reveals that policy impacts exhibit different patterns, depending on which model is used for estimation. Overall, with few exceptions, the OLS and IV models, which do not correct for self-selection, overestimate the marginal effects in comparison to the model that does make this correction. In principle, the self-selection biases could go in either direction. A possible explanation for the upward bias in our estimates is that there is a correlation between pronatal policies and researcher-unobserved preferences in the fertility regression's error term for self-selected households. This may arise because households with a strong desire to have children are more likely to self-select into municipalities that offer generous pronatal policies. Thus, we conclude that households' selfselection decisions across municipalities play an important role in estimating the effects of pronatal policies. Ignoring self-selection in migration decisions can induce substantial bias in the estimated effects of policy on fertility.

\section{Conclusion}

In this paper, we estimated the impacts of various municipality-sponsored pronatal policies on fertility in Japan. We were motivated by two questions: how do the self-selected migration decisions of households affect the estimated effects of pronatal policies on fertility, and which pronatal policies are more effective for which types of households? To answer these questions, we developed an empirical model that simultaneously accommodates households' migration and fertility decisions, and estimated the structural parameters of the model using microdata on Japanese households from metropolitan areas, after controlling for self-selected migration decisions. Substantial variation in pronatal policies across municipalities in Japan was used to identify the policy effects empirically.

Our main conclusion is that the self-selection decisions of households may generate substantial upward bias in the estimated impacts of policy on fertility. We also found that, even after controlling for self-selection, some noncash benefit pronatal policies significantly increase the probability of households having children, with the strength of these effects depending on household incomes and birth parity. 


\section{References}

Akabayashi, Hideo. 2006. "The Labor Supply of Married Women and Spousal Tax Deduction in Japan- A Structural Estimation." Review of Economics of the Household, 4(4): 349-378.

Andersson, Gunnar, Ann-Zofie Duvander, and Karsten Hank. 2004. "Do Child Care Characteristics Influence Continued Childbearing in Sweden? An Investigation of the Quantity, Quality, and Price Discrimination." Journal of European Social Policy, 14(4): 407-418.

Azmat, Ghazala, and Libertad Gonzalez. 2010. "Targeting Fertility and Female Participation through the Income Tax." Labour Economics, 17(3): 487-502.

Bayer, Patrick, Robert MacMillan, and Kim Rueben. 2005. "An Equilibrium Model of Sorting in an Urban Housing Market." NBER Working Paper No. 10865.

Berry, Steven, James Levinsohn, and Ariel Pakes. 1995. "Automobile Prices in Market Equilibrium." Econometrica, 63(4): 841-90.

Blau, David M., and Phillip K. Robins. 1989. "Fertility, Employment, and Child-Care Costs." Demography, 26(2): 287-299.

Brewer, Mike, Anita Ratcliffe, and Sarah Smith. 2011. "Does welfare reform affect fertility? Evidence from the UK." Journal of Population Economics, 25(1): 245-266.

Cohen, Alma, Rajeev Dehejia, and Dmitri Romanov. 2007. "Do Financial Incentives Affect Fertility." NBER Working Paper No. 13700.

Dahl, Gordon. 2002. "Mobility and the Return to Education: Testing a Roy Model with Multiple Marketsa." Econometrica, 70(6): 2367-2420.

Das, Mitali, Whitney Newey, and Francis Vella. 2003. "Nonparametric Estimation of Sample Selection Models." Review of Economic Studies, 70(1): 33-58.

Del Boca, Daniela. 2002. "The Effects of Child Care and Part Time Opportunities on Participation and Fertility Decisions in Italy." IZA Discussion Paper No. 427.

Ferreira, Fernando. 2010. "You Can Take It with You: Proposition 13 Tax Benefits, Residential Mobility, and Willingness to Pay for Housing Amenities." Journal of Public Economics, 94(9-10): 661-673.

Gauthier, Anne H. 2007. "The Impact of Family Policies on Fertility in Industrialized Countries: A Review of the Literature." Population Research and Policy Review, 26(3): 323-346. 
Gonzalez, Libertad. 2011. "The Effects of a Universal Child Benefit." mimeo, Universitat Pompeu Fabra.

Lalive, Rafael, and Josef Zweimuller. 2009. "How does Parental Leave Affect Fertility and Return to Work? Evidence from Two Natural Experiments." Quarterly Journal of Economics, 124(3): 1363-1402.

Laroque, Guy, and Bernard Salanié. 2008. "Does Fertility Respond to Financial Incentives." IZA Discussion Paper No. 3575.

Milligan, Kevin. 2005. "Subsidizing the Stork: New Evidence on Tax Incentives and Fertility." Review of Economics and Statistics, 87(3): 539-555.

Organization for Economic Co-operation and Development. 2007. "Can Policies Boost Birth Rates?" Policy Briefs, November.

Petrin, Amil, and Kenneth Train. 2010. "A Control Function Approach to Endogeneity in Consumer Choice Model." Journal of Marketing Research, 47(1): $3-13$.

Ronsen, Marit. 2004. "Fertility and Public Policies - Evidence from Norway and Finland." Demographic Research, 10(6): 143-170.

Roy, A. D. 1951. "Some Thoughts on the Distribution of Earnings." Oxford Economic Papers, 3(2): 135-146.

Wooldridge, Jeffrey M. 2010. Econometric Analysis of Cross Section and Panel Data. . 2nd ed., The MIT Press. 


\section{Appendix}

\section{Data appendix for municipality characteristics}

(1) Tokyo Metropolitan Dummy: unity if a municipality is one of the 23 special wards of the Tokyo Metropolitan Government.

(2) Major City Dummy: unity if a municipality is one of the 10 governmentordinance-designated cities, as of 2004.

(3) Crime Rate: the number of reported crime cases per head of population. Source: Criminal Statistics, National Police Agency.

(4) Unemployment Rate: the number of unemployed people as a proportion of the labor force. Source: Annual Report on the Labor Force Survey, Statistical Survey Department, Ministry of Internal Affairs and Communications.

(5) Rented Housing Proportion: the ratio of the number of rented houses to all houses. Source: Housing and Land Survey, Statistical Survey Department, Ministry of Internal Affairs and Communications.

(6) Financial Soundness Index: the ratio of standard financial revenues to standard financial needs. Source: Annual Statistical Report on Local Finance, Local Public Finance Bureau, Ministry of Internal Affairs and Communications.

(7) Supermarket Stores per Capita: the number of supermarket stores per head of population. Source: Establishment and Enterprise Census, Statistical Survey Department, Ministry of Internal Affairs and Communications.

(8) Doctors per Capita: the number of medical doctors per head of population. Source: Survey of Doctors, Dentists, Pharmacists, Statistics and Information Department, Ministry of Health, Labor, and Welfare.

(9) College Graduates per Capita: the number of college graduates per head of population. Source: Population Census, Statistical Survey Department, Ministry of Internal Affairs and Communications.

(10) Residential Land Price: the average land price of one square meter of residential land (in 10, 000 yen). Source: Land Price Survey by Prefectures, the Ministry of Land, Infrastructure, Transport, and Tourism.

Insert Table A.1 


\section{Tables}

Table 1: Sample Statistics for Household Characteristics and Pronatal Policies

\begin{tabular}{|c|c|c|c|c|c|}
\hline \multicolumn{6}{|c|}{ Panel A: Sample Statistics for Household Characteristics } \\
\hline & Sample Size & Mean & S.D. & Min & $\operatorname{Max}$ \\
\hline Child Dummy (Dependent Variable) & 5697 & 0.172 & 0.378 & 0.000 & 1.000 \\
\hline Wife's Age & 5697 & 39.149 & 6.088 & 21.000 & 49.000 \\
\hline Husband's Age & 5697 & 41.961 & 7.204 & 20.000 & 67.000 \\
\hline Husband's Annual Income & 5697 & 6.399 & 2.661 & 0.050 & 35.370 \\
\hline Preexisting First Child Dummy & 5697 & 0.239 & 0.426 & 0.000 & 1.000 \\
\hline Preexisting Second Child Dummy & 5697 & 0.436 & 0.496 & 0.000 & 1.000 \\
\hline Preexisting Third Child Dummy & 5697 & 0.144 & 0.351 & 0.000 & 1.000 \\
\hline Wife Labor Dummy & 5697 & 0.463 & 0.499 & 0.000 & 1.000 \\
\hline \multicolumn{6}{|c|}{ Panel B: Sample Statistics for Pronatal Policies b) } \\
\hline & Sample Size & Mean & S.D. & Min & Max \\
\hline Child Allowance & 277 & 0.091 & 0.612 & 0.000 & 7.448 \\
\hline Medical Subsidy & 277 & 1.093 & 0.981 & 0.000 & 13.473 \\
\hline Health Checkup Services & 277 & 0.271 & 0.271 & 0.000 & 2.649 \\
\hline Daycare Services Expenses & 277 & 9.736 & 6.674 & 0.000 & 32.462 \\
\hline Community-based Support & 277 & 0.101 & 0.333 & 0.000 & 5.350 \\
\hline \multicolumn{6}{|c|}{ Panel C: Correlation for Pronatal Policies } \\
\hline & Child & Medical & Health & Daycare & Community \\
\hline & Allowance & Subsidy & Checkups & Services & Support \\
\hline Child Allowance & 1.000 & & & & \\
\hline Medical Subsidy & 0.434 & 1.000 & & & \\
\hline Health Checkup Services & -0.004 & 0.093 & 1.000 & & \\
\hline Daycare Services Expenses & 0.085 & 0.108 & 0.025 & 1.000 & \\
\hline Community-based Support & -0.020 & 0.031 & 0.054 & -0.034 & 1.000 \\
\hline
\end{tabular}

\section{Notes:}

a) measured in million yen

b) measured in 10 thousand yen per child 
Table 2: Estimation Results: Location Choice Regression

\begin{tabular}{|c|c|c|c|c|}
\hline \multirow[b]{2}{*}{ Municipal Characteristics: } & \multicolumn{2}{|c|}{$\begin{array}{l}\text { Without Hedonic } \\
\text { Residual (1) }\end{array}$} & \multicolumn{2}{|c|}{$\begin{array}{l}\text { With Hedonic } \\
\text { Residual (2) }\end{array}$} \\
\hline & & & & \\
\hline Tokyo Metropolitan Dummy & $\begin{array}{c}-0.3745 \\
(0.1272)\end{array}$ & $* * *$ & $\begin{array}{r}-1.476 \\
(0.4227)\end{array}$ & $* * *$ \\
\hline Major City Dummy & $\begin{array}{r}1.797 \\
(0.0493)\end{array}$ & $* * *$ & $\begin{array}{r}1.8502 \\
(0.0512)\end{array}$ & $* * *$ \\
\hline Crime Rate & $\begin{array}{r}-6.532 \\
(3.3165)\end{array}$ & $* *$ & $\begin{array}{l}-12.3455 \\
(3.8359)\end{array}$ & $* * *$ \\
\hline Unemployment Rate & $\begin{array}{r}-12.9384 \\
(1.6948)\end{array}$ & $* * *$ & $\begin{array}{l}-15.1219 \\
(1.7545)\end{array}$ & $* * *$ \\
\hline Rented Housing Proportion & $\begin{array}{r}2.7143 \\
(0.2360)\end{array}$ & $* * *$ & $\begin{array}{r}2.3863 \\
(0.2884)\end{array}$ & $* * *$ \\
\hline Financial Index & $\begin{array}{r}0.4049 \\
(0.0936)\end{array}$ & $* * *$ & $\begin{array}{r}0.1300 \\
(0.1306)\end{array}$ & \\
\hline Supermarkets per Capita & $\begin{array}{r}0.4627 \\
(0.2812)\end{array}$ & * & $\begin{array}{l}-0.3754 \\
(0.3896)\end{array}$ & \\
\hline Doctors per Capita & $\begin{array}{r}7.1860 \\
(9.6869)\end{array}$ & & $\begin{array}{r}-0.1311 \\
(10.2904)\end{array}$ & \\
\hline College Grads per Capita & $\begin{array}{r}-0.5515 \\
(0.5085)\end{array}$ & & $\begin{array}{r}-4.7373 \\
(1.4905)\end{array}$ & $* * *$ \\
\hline Residential Land Price & $\begin{array}{l}-0.0298 \\
(0.0039)\end{array}$ & $* * *$ & $\begin{array}{r}0.0152 \\
(0.0163)\end{array}$ & \\
\hline$\underset{\hat{\nu}}{\operatorname{Hedonic}}$ Residual & & & $\begin{array}{l}-0.0532 \\
(0.0168)\end{array}$ & $* * *$ \\
\hline$\hat{\nu}^{2}$ & & & $(0.0007)$ & $* * *$ \\
\hline D & & & $\begin{array}{r}0.0001 \\
(0.0000)\end{array}$ & $* * *$ \\
\hline $\begin{array}{l}\text { Pronatal Policies Levels: } \\
\text { Child Allowance }\end{array}$ & 0.0553 & & 0.0324 & \\
\hline Medical Subsidy & $\begin{array}{l}(0.0805) \\
-0.1055 \\
(0.0670)\end{array}$ & & $\begin{array}{r}(0.0818) \\
-0.0961 \\
(0.0669)\end{array}$ & \\
\hline Health Checkup Services & $\begin{array}{r}0.2901 \\
(0.1707)\end{array}$ & $*$ & $\begin{array}{r}0.2875 \\
(0.1731)\end{array}$ & $*$ \\
\hline Daycare Services Expenses & 0.0068 & & $\begin{array}{r}0.0026 \\
(0.0081\end{array}$ & \\
\hline Community-based Support & $\begin{array}{l}-0.6976 \\
(0.4495)\end{array}$ & & $\begin{array}{l}-0.6916 \\
(0.4413)\end{array}$ & \\
\hline $\begin{array}{l}\text { Pronatal Policies with Hus. Income: } \\
\text { Child Allowance }\end{array}$ & $\begin{array}{r}0.0026 \\
(0.0098)\end{array}$ & & $\begin{array}{r}0.0021 \\
(0.0099)\end{array}$ & \\
\hline Medical Subsidy & $\begin{array}{r}-0.0055 \\
(0.0082)\end{array}$ & & $\begin{array}{r}-0.0059 \\
(0.0082)\end{array}$ & \\
\hline Health Checkup Services & $\begin{array}{r}-0.0097 \\
(0.0210)\end{array}$ & & $\begin{array}{r}-0.0116 \\
(0.0212)\end{array}$ & \\
\hline Daycare Services Expenses & $\begin{array}{r}0.0003 \\
(0.0009)\end{array}$ & & $\begin{array}{r}0.0003 \\
(0.0009\end{array}$ & \\
\hline Community-based Support & $\begin{array}{l}-0.0524 \\
(0.0378)\end{array}$ & & $(0.0369)$ & \\
\hline $\begin{array}{l}\text { Pronatal Policies with Preexisting Child: } \\
\text { Child Allowance }\end{array}$ & $\begin{array}{r}0.0223 \\
(0.0698)\end{array}$ & & $\begin{array}{r}0.0230 \\
(0.0706)\end{array}$ & \\
\hline Medical Subsidy & $\begin{array}{l}-0.0361 \\
(0.0547)\end{array}$ & & $\begin{array}{l}-0.0324 \\
(0.0546)\end{array}$ & \\
\hline Health Checkup Services & $\begin{array}{l}-0.1720 \\
(0.1352)\end{array}$ & & $\begin{array}{r}-0.1697 \\
(0.1364)\end{array}$ & \\
\hline Daycare Services Expenses & $\begin{array}{r}-0.0022 \\
(0.0065)\end{array}$ & & $(0.0065)$ & \\
\hline Community-based Support & $\begin{array}{r}0.8306 \\
(0.4079)\end{array}$ & $* *$ & $\begin{array}{r}0.7774 \\
(0.4009)\end{array}$ & $*$ \\
\hline Sample Size & 172012 & & 172012 & \\
\hline
\end{tabular}


Table 3: Estimation Results: Wife's Labor Force Participation Regression

\begin{tabular}{|c|c|c|}
\hline \multicolumn{3}{|l|}{ Household Characteristics: } \\
\hline & $\begin{array}{r}0.0162 \\
(0.0020)\end{array}$ & FA \\
\hline Husband's Age & $\begin{array}{r}0.0042 \\
(0.0017)\end{array}$ & $* *$ \\
\hline Husband's Annual Income & $\begin{array}{l}-0.0484 \\
(0.0202)\end{array}$ & $* * *$ \\
\hline Husband Annual Income ${ }^{2}$ & $\begin{array}{r}0.0026 \\
(0.0018)\end{array}$ & \\
\hline Husband Annual Income ${ }^{3}$ & -0.0000 & \\
\hline Preexisting 1st Child & $\begin{aligned}(0.00000) \\
-0.0726 \\
(0.0463)\end{aligned}$ & \\
\hline Preexxisting 2nd Child & $\begin{array}{r}0.0099 \\
(0.0457)\end{array}$ & \\
\hline Preexisting 3rd Child & $\begin{array}{r}0.0382 \\
(0.0479)\end{array}$ & \\
\hline $1\left(s_{i}>4.83\right)$ & -0.0113 & \\
\hline $1\left(s_{i}>11.31\right)$ & $\begin{array}{r}-0.0876 \\
(0.0507)\end{array}$ & * \\
\hline $\begin{array}{l}\text { Pronatal Policies Levels: } \\
\text { Child Allowance }\end{array}$ & $\begin{array}{l}-0.0332 \\
(0.0481)\end{array}$ & \\
\hline Medical Subsidy & $\begin{array}{r}0.0034 \\
(0.0338)\end{array}$ & \\
\hline Health Checkup Services & $\begin{array}{r}0.1539 \\
(0.0924)\end{array}$ & * \\
\hline Daycare Services Expenses & $\begin{array}{r}0.0059 \\
(0.0040)\end{array}$ & \\
\hline Community-based Support & $\begin{array}{l}-0.3706 \\
(0.2035)\end{array}$ & * \\
\hline $\begin{array}{l}\text { Pronatal Policies with Hus. Income: } \\
\text { Child Allowance }\end{array}$ & $\begin{array}{r}0.0056 \\
(0.0063)\end{array}$ & \\
\hline Medical Subsidy & $\begin{array}{l}-0.0071 \\
(0.0039)\end{array}$ & * \\
\hline Health Checkup Services & $\begin{array}{l}-0.0182 \\
(0.0114)\end{array}$ & \\
\hline Daycare Services Expenses & $\begin{array}{l}-0.0003 \\
(0.0005)\end{array}$ & \\
\hline Community-based Support & $\begin{array}{r}0.0202 \\
(0.0141)\end{array}$ & \\
\hline $\begin{array}{l}\text { Pronatal Policies with Preexisting Child: } \\
\text { Child Allowance }\end{array}$ & $\begin{array}{r}-0.0151 \\
(0.0290)\end{array}$ & \\
\hline Medical Subsidy & $\begin{array}{r}0.0384 \\
(0.0275)\end{array}$ & \\
\hline Health Checkup Services & $\begin{array}{r}0.0013 \\
(0.0729)\end{array}$ & \\
\hline Daycare Services Expenses & $\begin{array}{l}-0.0048 \\
(0.0032)\end{array}$ & \\
\hline Community-based Support & $\begin{array}{r}0.2403 \\
(0.1891)\end{array}$ & \\
\hline Constant & $\begin{array}{l}0.1015 \\
(0.1535) \\
\end{array}$ & \\
\hline Sample Size & 5697 & \\
\hline
\end{tabular}


Table 4: Estimation Results: Fertility Regression

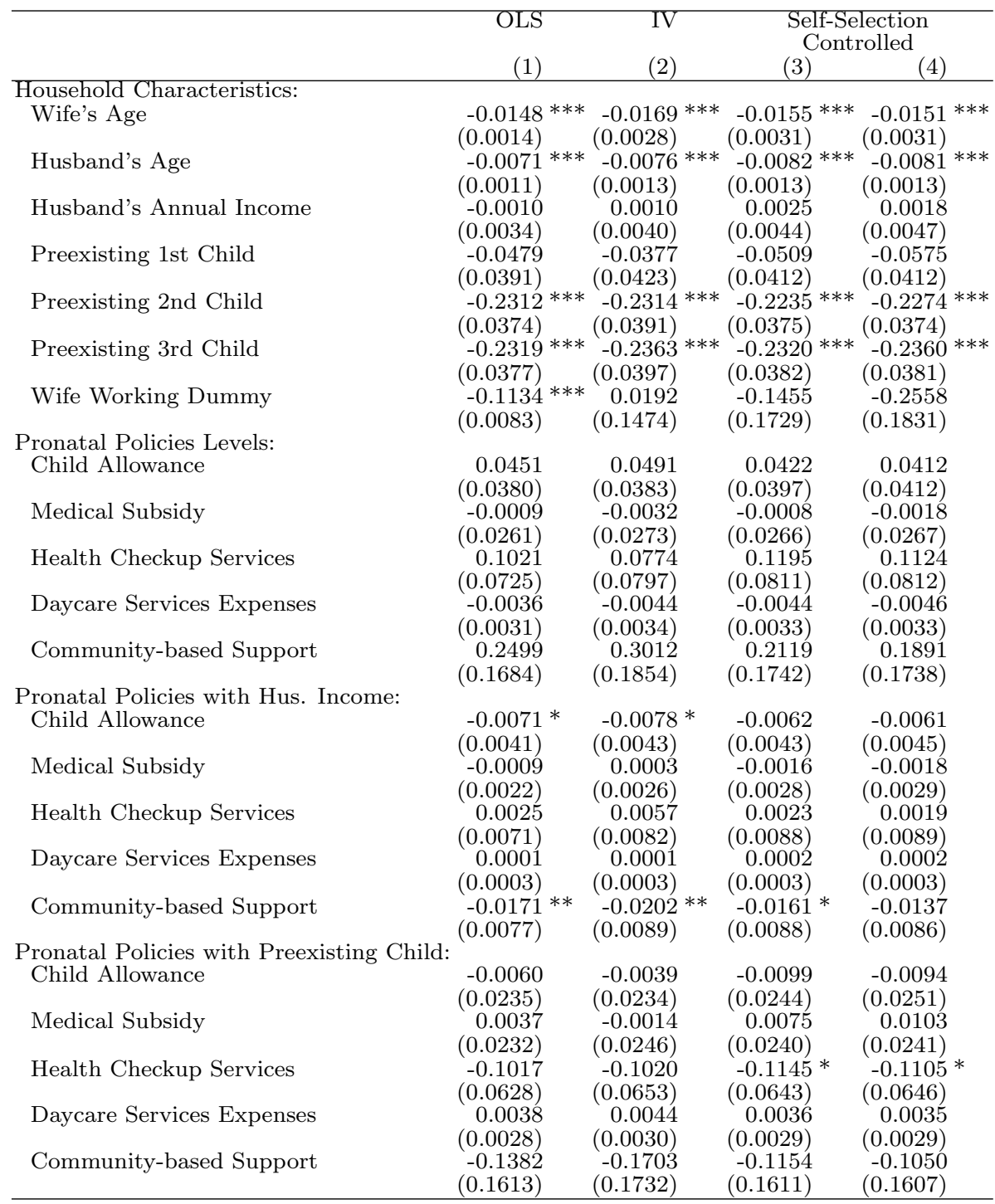




\begin{tabular}{|c|c|c|c|c|}
\hline \multirow{2}{*}{\multicolumn{5}{|c|}{$\begin{array}{l}\text { Estimation Results: Fertility Regression (Continued) } \\
\text { Municinal Characteristics: }\end{array}$}} \\
\hline & & & & \\
\hline \multicolumn{5}{|c|}{$\begin{array}{llll}\text { Tokyo Metropolitan Dummy } & 0.0066 & -0.0076 & -0.0213\end{array}$} \\
\hline \multirow{2}{*}{ Major City Dummy } & 0.0061 & 0.0053 & -0.0096 & -0.0109 \\
\hline & $(0.0137)$ & $(0.0142)$ & $(0.0206)$ & $(0.0206)$ \\
\hline \multirow[t]{2}{*}{ Crime Rate } & -0.2651 & -0.1495 & -0.5640 & -0.5862 \\
\hline & $(0.9119)$ & $(0.9623)$ & $(0.9712)$ & $(0.9714)$ \\
\hline \multirow{2}{*}{ Unemployment Rate } & -0.1249 & 0.0902 & 0.2253 & 0.1367 \\
\hline & $(0.3928)$ & $(0.4762)$ & $(0.4919)$ & $(0.4925)$ \\
\hline \multirow[t]{2}{*}{ Rented Housing Proportion } & 0.0321 & 0.0265 & 0.0813 & 0.0938 \\
\hline & $(0.0683)$ & $(0.0717)$ & $(0.0734)$ & $(0.0732)$ \\
\hline \multirow[t]{2}{*}{ Financial Soundness Index } & 0.0240 & 0.0228 & 0.0235 & 0.0152 \\
\hline & $(0.0273)$ & $(0.0285)$ & $(0.0303)$ & $(0.0305)$ \\
\hline Supermarkets per Capita & $\begin{array}{r}-0.0178 \\
(0.1014)\end{array}$ & $(0.1037)$ & $\begin{array}{r}-0.0258 \\
(0.1118)\end{array}$ & $(0.1135)$ \\
\hline \multirow[t]{2}{*}{ Doctors per Capita } & -3.0914 & -2.0605 & -4.0644 & -5.1466 \\
\hline & $(4.0493)$ & $(4.3226)$ & $(4.5193)$ & $(4.6016)$ \\
\hline \multirow[t]{2}{*}{ College Grads per Capita } & -0.2008 & -0.0750 & -0.1792 & -0.1836 \\
\hline & & $(0.1930)$ & $(0.2005)$ & $(0.2073)$ \\
\hline Residual & & $\begin{array}{l}-0.1331 \\
(0.1476)\end{array}$ & $\begin{array}{r}0.1966 \\
(0.1940)\end{array}$ & $\begin{array}{r}0.4368 \\
(0.2591)\end{array}$ \\
\hline \multicolumn{2}{|l|}{ Residual $^{2}$} & & $\begin{array}{l}-1.0593 \text { *** } \\
(0.1604)\end{array}$ & $\begin{array}{l}-1.0127 * * * \\
(0.1548)\end{array}$ \\
\hline \multicolumn{2}{|l|}{ Residual $^{3}$} & & $\begin{array}{l}-0.5169 \text { *** } \\
(0.1617)\end{array}$ & $\begin{array}{l}-1.2849 \\
(0.6809)\end{array}$ \\
\hline Residual $^{4}$ & & & $\begin{array}{l}1.4307^{* * *} \\
(0.2904)\end{array}$ & $\begin{array}{l}1.3290 \text { *** } \\
(0.2733)\end{array}$ \\
\hline \multicolumn{2}{|l|}{ Residual $^{5}$} & & $\begin{array}{l}-0.8 \\
0.54\end{array}$ & $\begin{array}{r}0.9437 \\
(0.8034)\end{array}$ \\
\hline \multicolumn{2}{|l|}{ Propensity } & & $\begin{array}{c}7.4184 \\
(4.1305)\end{array}$ & $\begin{array}{r}1.0395 \\
(1.0234)\end{array}$ \\
\hline \multicolumn{2}{|l|}{ Propensity $^{2}$} & & $\begin{array}{l}-20.25 \\
10.57\end{array}$ & $\begin{array}{r}-18.3437 \\
(12.7833)\end{array}$ \\
\hline \multicolumn{2}{|l|}{ Propensity $^{3}$} & & $\begin{array}{l}16.4722 \\
(8.5780)\end{array}$ & $\begin{array}{l}110.2711 \text { * } \\
(62.4750)\end{array}$ \\
\hline \multicolumn{2}{|l|}{ Propensity $^{4}$} & & $\begin{array}{r}0.0546 \\
(0.0848)\end{array}$ & $\begin{array}{l}-244.9775 * \\
(124.1199)\end{array}$ \\
\hline \multicolumn{2}{|l|}{ Propensity $^{5}$} & & & $\begin{array}{l}177.7303^{* *} \\
(84.4808)\end{array}$ \\
\hline \multicolumn{2}{|l|}{ Residual $\times$ Propensity } & & & $\begin{array}{r}0.0575 \\
(0.0850)\end{array}$ \\
\hline \multirow[t]{2}{*}{ Constant } & $\begin{array}{l}1.2611 \text { *** } \\
(0.0635)\end{array}$ & $\begin{array}{l}1.2615 \text { *** } \\
(0.0661)\end{array}$ & $\begin{array}{l}1.4670 \text { *** } \\
(0.0762)\end{array}$ & $\begin{array}{l}1.4932 \text { *** } \\
(0.0852)\end{array}$ \\
\hline & 5587 & 5587 & 5587 & 5587 \\
\hline
\end{tabular}

Notes: Standard errors are in parentheses.

$* * *$ denotes statistically significant at $1 \%$ level

** denotes statistically significant at $5 \%$ level

* denotes statistically significant at $10 \%$ level 
Table 5: Effects of Pronatal Policies on Fertility (10 Percent Increases): Estimates are Based on Model with Self-selection Correction

\begin{tabular}{|c|c|c|c|c|c|c|c|c|c|c|}
\hline & \multicolumn{10}{|c|}{ Husband Annual Revenue (in million yen) } \\
\hline & 1.00 & 2.00 & 3.00 & 4.00 & 5.00 & 6.00 & 7.00 & 8.00 & 9.00 & 10.00 \\
\hline \multicolumn{11}{|c|}{ Households w/ Child or Children } \\
\hline Child Allowance & 0.103 & 0.088 & 0.041 & 0.021 & 0.008 & -0.006 & -0.024 & -0.052 & -0.082 & -0.124 \\
\hline Medical S & 0.376 & 0.306 & 0.133 & 0.058 & 0.003 & -0.058 & -0.132 & -0.258 & -0.386 & 566 \\
\hline ckup Services & 0.043 & 077 & 0.070 & 0.074 & 0.093 & 0.119 & 0.148 & 0.216 & & 46 \\
\hline $\mathrm{D}$ & -0.459 & 01 & -0.196 & -0.113 & -0.062 & -0.0 & & 0.161 & & 435 \\
\hline Community-based Support & $0.294^{*}$ & $0.262 *$ & * $0.132 *$ & 0.080 & 0.050 & 0.020 & -0.019 & -0.075 & & -0.231 \\
\hline \multicolumn{11}{|c|}{ Households w/o Child or Children } \\
\hline Child Allowance & 0.050 & & & & & & & & & \\
\hline osidy & -0.061 & -0.094 & -0.116 & -0.128 & -0.169 & -0.200 & -0.254 & -0.317 & -0.410 & -0.470 \\
\hline Clorv & 0.597 & & 0.577 & $0.501^{*}$ & $0.560^{*}$ & $0.570^{*}$ & $0.637^{* *}$ & $0.712 * *$ & $0.841 *$ & * $0.878^{*}$ \\
\hline e Services Expenses & -0.823 & -0.794 & -0.715 & -0.584 & -0.615 & -0.588 & -0.613 & -0.640 & -0.706 & -0.678 \\
\hline Community-based Support & 0.258 & 0.240 & 0.208 & 0.161 & 0.161 & 0.145 & 0.139 & 0.132 & 0.130 & 0.106 \\
\hline
\end{tabular}

Notes: All effects are measured in percentage increase of childbearing probability.

*denotes statistically significant at $10 \%$ level

$* *$ denotes statistically significant at $5 \%$ level 
Table A.1: Sample Statistics for Municipality Characteristics

\begin{tabular}{lrrrrr}
\hline & Sample Size & Mean & S.D. & Min & Max \\
\hline Tokyo Metropolitan Dummy & 5697 & 0.035 & 0.185 & 0.000 & 1.000 \\
Major City Dummy & 5697 & 0.193 & 0.394 & 0.000 & 1.000 \\
Crime Rate & 5697 & 0.024 & 0.007 & 0.010 & 0.053 \\
Unemployment Rate & 5697 & 0.061 & 0.015 & 0.030 & 0.194 \\
Rented Housing Proportion & 5697 & 0.335 & 0.091 & 0.042 & 0.518 \\
Financial Soundness Index & 5697 & 0.876 & 0.224 & 0.200 & 1.780 \\
Supermarkets per Capita & 5697 & 0.142 & 0.052 & 0.000 & 1.057 \\
Doctors per Capita & 5697 & 0.002 & 0.001 & 0.000 & 0.015 \\
College Graduates per Capita & 5697 & 0.138 & 0.042 & 0.030 & 0.288 \\
Residential Land Price & 637 & 9.751 & 9.469 & 0.510 & 92.630 \\
\hline
\end{tabular}

Table A.2: Estimates of Municipality Characteristics: Wife's Labor Force Participation Regression

\begin{tabular}{|c|c|c|}
\hline \multicolumn{3}{|l|}{ Municipal Characteristics: } \\
\hline Tokyo Metropolitan Dummy & $\begin{array}{r}0.1510 \\
(0.1900)\end{array}$ & \\
\hline Major City Dummy & 0.0116 & \\
\hline Crime Rate & $\begin{array}{l}(0.0213) \\
-1.1627 \\
(1.6703)\end{array}$ & \\
\hline Unemployment Rate & $\begin{array}{r}-1.635 \\
(0.6302)\end{array}$ & $* * *$ \\
\hline Rented Housing Proportion & $\begin{array}{r}0.0851 \\
(0.1307)\end{array}$ & \\
\hline Financial Soundness Index & 0.0158 & \\
\hline Supermarkets per Capita & $\begin{array}{r}0.0781 \\
(0.1943)\end{array}$ & \\
\hline Doctors per Capita & $\begin{array}{r}-7.5045 \\
(6.5314)\end{array}$ & \\
\hline College Grads per Capita & $\begin{array}{r}-0.8041 \\
(0.6984)\end{array}$ & \\
\hline Residential Land Price & $\begin{array}{r}-0.0017 \\
(0.0076)\end{array}$ & \\
\hline$\underset{\hat{\nu}}{\operatorname{Hedonic}}$ Residual & $\begin{array}{r}-0.0015 \\
(0.0077)\end{array}$ & \\
\hline$\hat{\nu}^{2}$ & $\begin{array}{r}-0.0007 \\
(0.0003)\end{array}$ & $* *$ \\
\hline$\hat{\nu}^{3}$ & $\begin{array}{r}0 \\
(0.0000) \\
\end{array}$ & $* *$ \\
\hline $\begin{array}{l}\text { Note: Standard errors are in } \\
* * * \text { denotes statistically signif } \\
* * \text { denotes statistically signifi } \\
* \text { denotes statistically significa }\end{array}$ & $\begin{array}{l}\text { entheses. } \\
\text { nt at } 1 \% \\
\text { t at } 5 \% \text { le } \\
\text { at } 10 \%\end{array}$ & $\begin{array}{l}\text { vel } \\
\text { el }\end{array}$ \\
\hline
\end{tabular}




\section{Figures}

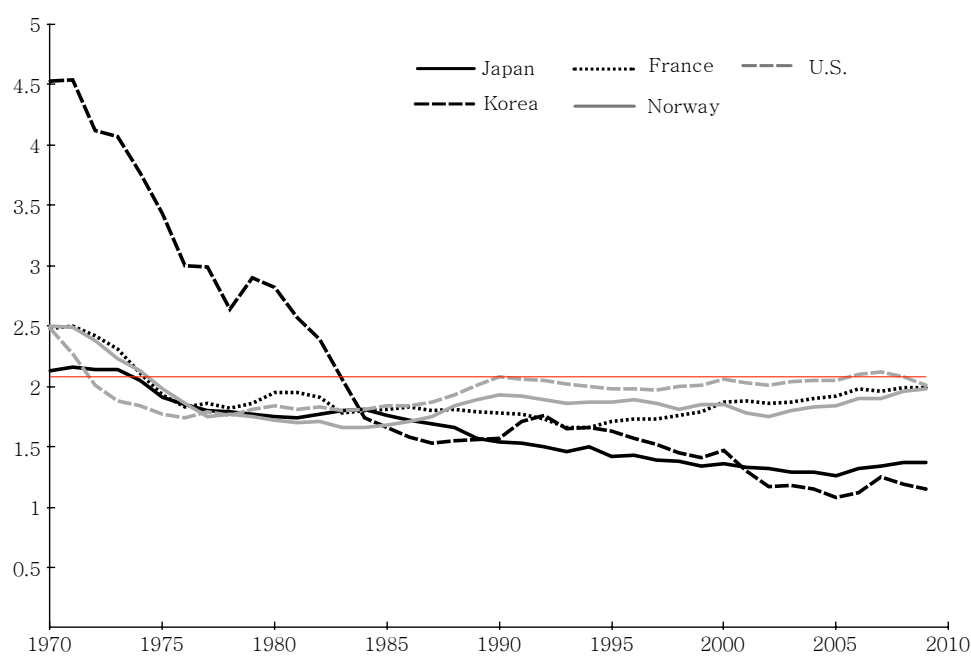

Note: The horizontal line corresponds the replacement level of fertility, that is, the number of children each woman needs to have to maintain current population levels.

Figure 1: Trends in Total Fertility Rates in Selected OECD Countries 

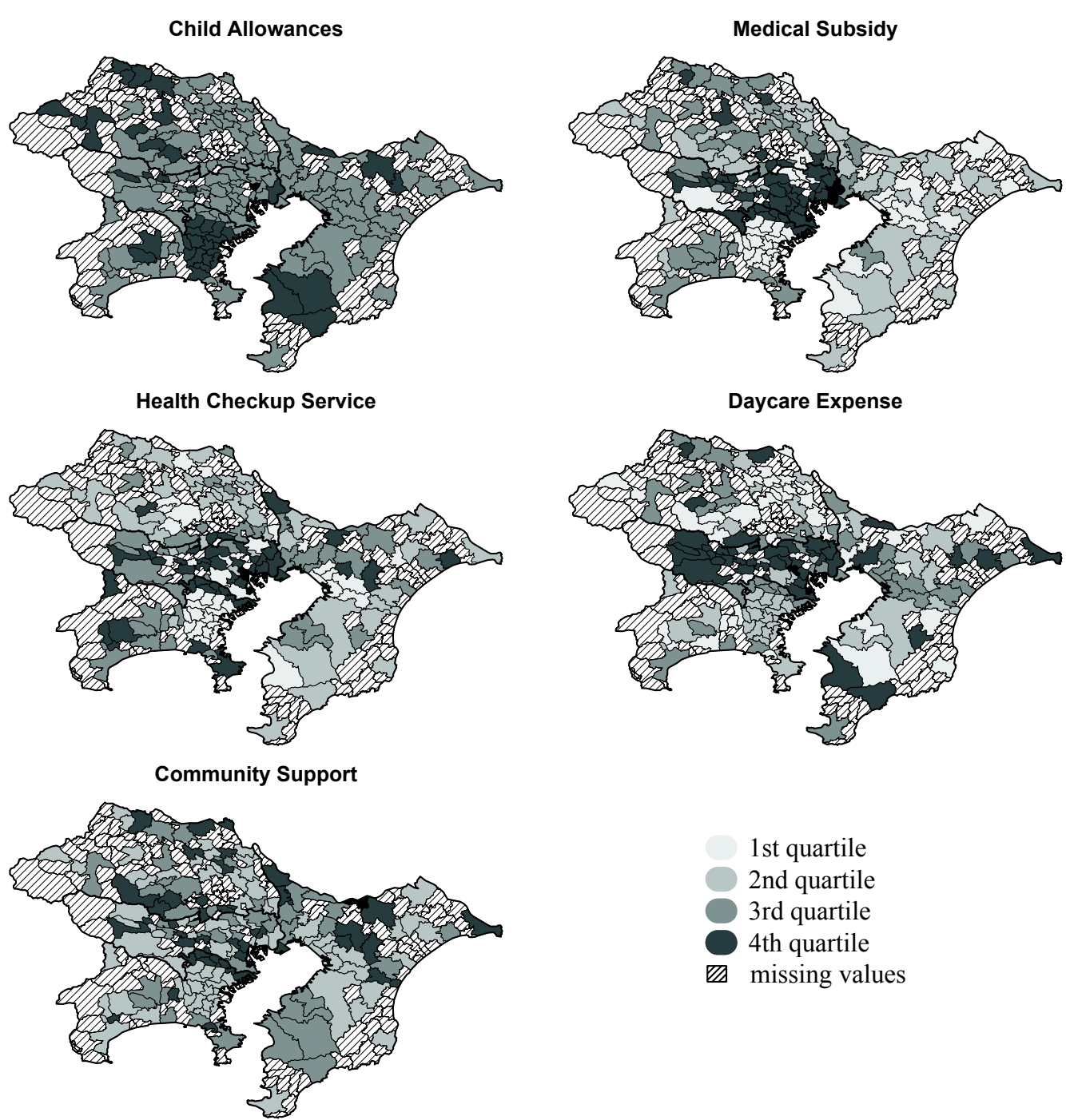

1st quartile

2nd quartile

3rd quartile

4th quartile

ए missing values

Figure 2: Variation Maps of Pronatal Policies for the Tokyo Metropolitan Area 


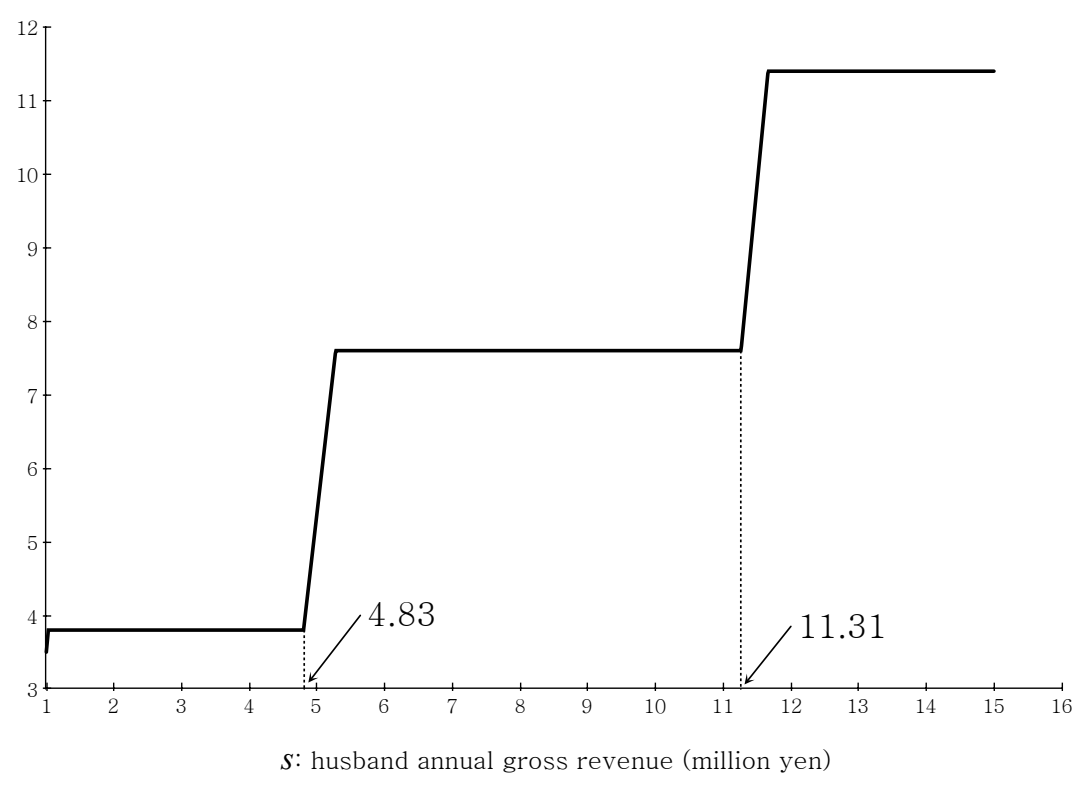

Figure 3: Difference in Annual Tax Deduction between a Household in which a Wife's Gross Annual Income is Below the Spousal Deduction Eligibility Threshold and a Household in which the Wife's Gross Annual Income is Above the Threshold (10,000 yen) 


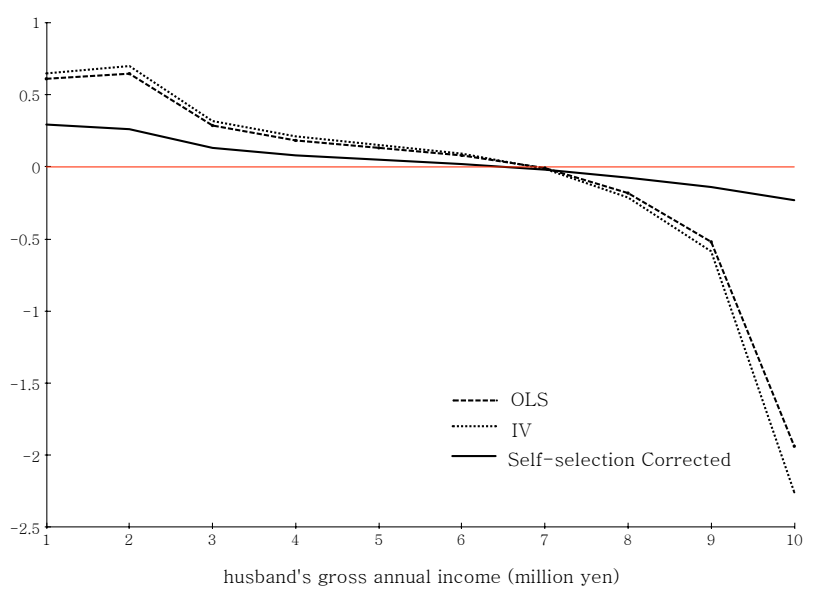

(a) Community-based Support

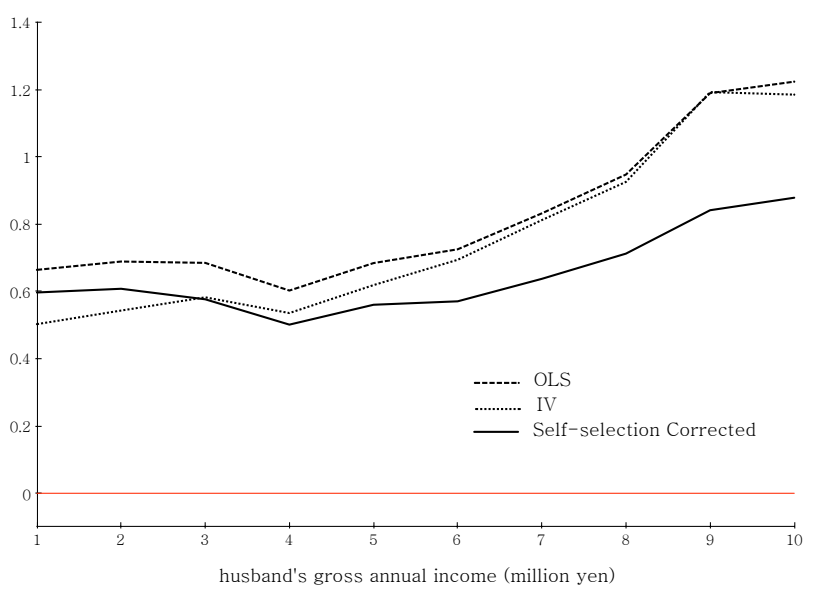

(b) Health Checkup Services

Figure 4: Comparison of the Estimated Pronatal Effects of Policy on Fertility between Specifications: OLS, IV, and Self-selection Controlled Model. (Figures represent percentage increases in fertility probability when the corresponding policy expenditure is increased by 10 percent.) 